\title{
The hydroxyproline content of fish bone gelatin from Indonesian Pangasius catfish by enzymatic hydrolysis for producing the bioactive peptide
}

\author{
YONI ATMA ${ }^{1, \vartheta}$, HANIFAH NURYANI LIOE ${ }^{2, v \vee}$, ENDANG PRANGDIMURTI $^{2}$, HERMAWAN SEFTIONO $^{1}$, \\ MOH. TAUFIK ${ }^{1}$, DITA FITRIANI ${ }^{1}$, APON ZAENAL MUSTOPA ${ }^{3}$ \\ ${ }^{1}$ Department of Food Science and Technology, Faculty of Bioindustry, Universitas Trilogi. Jl. Taman Makam Pahlawan Kalibata, Jakarta 12760, \\ Indonesia. Tel./fax.: +62-21-7980011, ^email: yoniatma@trilogi.ac.id \\ ${ }^{2}$ Department of Food Science and Technology, Faculty of Agricultural Engineering, Institut Pertanian Bogor. J1. Raya Dramaga, Bogor 16680, West \\ Java, Indonesia. " email: hanifahlioe@apps.ipb.ac.id \\ ${ }^{3}$ Research Center for Biotechnology, Indonesian Institute of Sciences. Jl. Raya Jakarta-Bogor Km 46, Cibinong, Bogor 16912, West Java, Indonesia
}

Manuscript received: 24 June 2018. Revision accepted: 21 August 2018

\begin{abstract}
Atma Y, Lioe HN, Prangdimurti E, Seftiono H, Tahufik M, Fitriani D, Mustopa AZ. 2018. The hydroxyproline content on fish bone gelatin from Indonesian Pangasius catfish by enzymatic hydrolysis for producing of bioactive peptide. Biofarmasi J Nat Prod Biochem 16: 64-68. Gelatins have been widely used in the food, medicines, cosmetics, and photography industries. In the food industry, gelatin is used as a food additive and in functional foods. The applications of gelatin as a functional food are due to its bioactivity in the form of peptides. Bioactive peptides from gelatin are mostly obtained through enzymatic hydrolysis processes. This study was conducted to measure the hydroxyproline content of the gelatin bone of Indonesian Pangasius catfish (Pangasius sutchi) before and after enzymatic hydrolysis. Hydroxyproline is one of the dominant amino acids in gelatin. Gelatin hydrolysis was carried out using a flavourzyme at a concentration of $6 \%$ and the incubation series of $0,4,6$, and 8 hours. The standard hydroxyproline concentration was used in the range of $0-1 \mu \mathrm{g}$. The results showed that the linear curve of the standard hydroxyproline solution was $\mathrm{y}=0.0554 \mathrm{x}+0.0406$, with the coefficient of determination $\left(\mathrm{R}^{2}\right)=0.9435$. The incubation time of enzymatic hydrolysis $(6 \%$ enzyme concentration) affected the hydroxyproline content. The hydroxyproline from fishbone gelatin was $18.91 \pm 2.87 \mathrm{mg} / \mathrm{mL}, 63.81 \pm 1.28 \mathrm{mg} / \mathrm{mL}, 46.21 \pm 1.28 \mathrm{mg} / \mathrm{mL}$ and $37.64 \pm 0.64 \mathrm{mg} / \mathrm{mL}$ respectively during $0,4,6$ dan $8 \mathrm{~h}$ incubation time. This hydroxyproline content was significantly different at a $95 \%$ confidence level from each treatment time.
\end{abstract}

Keywords: Bioactive peptide, enzymatic hydrolysis, fishbone gelatin, hydroxyproline

\section{INTRODUCTION}

Gelatin is a collagen hydrolysate with molecular weight ranging from $97 \mathrm{kDa}$ to $>250 \mathrm{kDa}$, produced in acid or alkaline conditions. It has been used in various industries, including food, medicines, cosmetics, and photographs (Mariod and Fadul 2013). In food industries, gelatin was used as food additives and functional food. As a food additive, gelatin was used as an emulsifier, stabilizer, gelling former, thickener, adhesive agent, and biofilm. While as functional food, gelatin has been developed in peptides for antidiabetic, antimicrobial, antioxidant, and antihypertensive (Gómez-Guillén et al. 2011).

The research regarding gelatin as a functional food has grown rapidly, especially about fish-based gelatin utilization (Aleman et al., 2011; Koli et al., 2014; Nikoo et al., 2014). Fish-based gelatin could potentially replace mammalian gelatin, which is the most source of gelatin; however, it is unacceptable due to religious, socio-cultural, and health considerations (Nurul and Sarbon 2015). Many previous studies have reported that the fish gelatins have their bioactivities, for example, the gelatin from salmon, hake, halibut, nila tilapia, pangasius catfish, etc. (Li-Chan et al. 2012; Mahmoodani et al. 2014a; Wang et al. 2015).
Fortunately, most fish-based gelatin comes from byproducts of fish processing waste (Karayannakidis and Zotos 2016). Therefore, the utilization of this source could be promising in the future, especially in Indonesia.

Indonesia is a country with a wide water area, so it provides biodiversity in fisheries. There are two types of fish based on their habitat: warm-water fish and cold-water fish. In cases of gelatin sources, it has been known that the gelatin from warm-water fish has superior characteristics compared to the other one (Gómez-Guillén et al. 2009). One warm-water fish with a high production yield in Indonesia is the Pangasius catfish (Pangasius sutchi). In Indonesia, Pangasius catfish spread out in Sumatera and Kalimantan. In addition, the consumption and production rate of this fish has increased every year. The Ministry of Marine Affairs and Fisheries targeted the Pangasius catfish production in 2018, reaching 604.587 tons. It will inflict waste, especially fishbone, contributing about $12.44 \%$ of the total fish weight. Previous studies concluded that gelatin from the bone of Pangasius catfish was better than other fish-based on gelatin in physicochemical characteristics. The gelatin from this source was also comparable with commercial bovine gelatin (Mahmoodani et al. 2014b). 
The aim of this research was to analyze the hydroxyproline of gelatin from Indonesian Pangasius catfish (Pangasius sutchi) before and after hydrolysis enzymatic. Most bioactive peptide extraction from gelatin resulted from gelatin hydrolyzation followed by hydroxyproline content measurement (Li-Chan et al. 2012; Mahmoodani et al. 2014a; Nikoo et al. 2014). The hydrolysis of gelatin is mostly and more efficient using protease. Determining this hydroxyproline content could become a basic knowledge to know and characterize the influence of hydrolysis toward hydroxyproline of fishbone gelatin from Pangasius catfish. According to the bioactive peptide production, it could also become a comparable study in the hydroxyproline content of fish-based gelatin.

\section{MATERIALS AND METHODS}

\section{Study area}

This experimental research was conducted in four stages, including the gelatin extraction of Pangasius catfish bone, fishbone gelatin hydrolysis, the measurement of the hydroxyproline content, and data analysis. The fish bones used for gelatin extraction were Pangasius sutchi from Indonesian rivers in Riau province.

\section{Procedures}

\section{Gelatin extraction}

The gelatin extraction was done in two steps, i.e., pretreatment and main extraction. The pre-treatment of fish bones was done by soaking them with a mild acid (citric acid) for $48 \mathrm{~h}$. After the pre-treatment steps, the leached bone (ossein) was separated with pre-treatment solvent using a centrifuge (Hettich, USA) at $4000 \mathrm{rpm}$ for 15 minutes, followed by main extraction steps using hot water $\left(75^{\circ} \mathrm{C}\right)$ for $5 \mathrm{~h}$. Afterward, the main extraction solvent was separated with liquid extract using filter paper (Whatman Grade 4, USA). Finally, this liquid extract, namely liquid extract of fishbone gelatin, was collected in a tube and stored at $4^{\circ} \mathrm{C}$ until further hydrolysis and analysis.

\section{Gelatin hydrolysis}

Fishbone gelatin obtained from gelatin extraction stages was firstly incubated at $50^{\circ} \mathrm{C}$ for 10 minutes. Subsequently, the flavourzyme (Sigma, Germany) was added with enzyme/substrate (E/S) with a ratio of $6 \%$. Afterward, this solution contained gelatin and flavourzyme $(6 \%)$ and was incubated for 4,6 , and $8 \mathrm{~h}$. The enzymatic hydrolysis process was stopped using hot water $\left(100^{\circ} \mathrm{C}\right)$ for 10 minutes, then soaked in cool water for 20 minutes. In the last step, the hydrolysis gelatin was obtained by separation using a centrifuge (Hitachi, Japan) at $1000 \mathrm{rpm}$ for $15 \mathrm{~min}$ at $4^{\circ} \mathrm{C}$. The supernatant, called fishbone gelatin, was stored at $-18^{\circ} \mathrm{C}$ for measurement analysis of their hydroxyproline content.

\section{Hydroxyproline analysis}

Hydroxyproline analysis of fishbone gelatin was carried out as follows: preparation sample, reagent addition, and absorbance measurement, as described by Koli et al. (2014). The preparation sample of gelatin was done by adding $12 \mathrm{~N}$ hydrogen chloride into the sample, followed by incubation at $100^{\circ} \mathrm{C}$ for $3 \mathrm{~h}$. Afterward, the gelatin was filtered through filter paper. Whatman no. 4. The filtrate gelatin was then added to a chloramine reagent containing $1.4 \%$ chloramine $\mathrm{T}$ (Biovision, USA) and oxidant buffer (Biovision, USA) ratio of 1: 10. After the incubation for 5 min at room temperature, the sample of gelatin was added p-dimethylaminobenzaldehyde (DMAB) reagent containing $10 \%$ of DMAB concentration (Biovision, USA) and $60 \%$ of perchloric acid (Biovision, USA) in ratio 1: $1(\mathrm{v} / \mathrm{v})$. This solution was then incubated at $60^{\circ} \mathrm{C}$ for 90 minutes and continued with cooling for 2-3 minutes. At last, the solution was measured for its absorbance using a spectrophotometer (Thermo Multiskan, USA) at a wavelength of $540 \mathrm{~nm}$. Hydroxyproline e kit (Biovision, USA) was used to measure the hydroxyproline content in fishbone gelatin before and after enzymatic hydrolysis. The concentration of hydroxyproline used in this analysis was $0-1 \mu \mathrm{g} /$ well. The hydroxyproline quantification was done after the linear curve of the standard hydroxyproline solution was obtained.

\section{Data analysis}

Data analysis was performed using one-way Analysis of Variant (ANOVA) at level 5\% and continued with Tukey's HSD (Honestly Significant Different) test or Tukey's range test to determine the statistical analysis at the level of significant differences between data.

\section{RESULTS AND DISCUSSION}

\section{Fishbone gelatin hydrolysis}

There are some stages for the production of the bioactive peptide from the gelatin, including (i) gelatin extraction, (ii) gelatin hydrolysis, (iii) the hydrolysate filtration by ultrafiltration, (iv) gelatin purification, and (v) analysis of the sequence after purification (Zhang et al. 2012; Li-Chan et al. 2012). The bioactivities of gelatin in each stage must be measured. In this research, a part of gelatin extraction and gelatin hydrolysis using the bone of Pangasius catfish (Pangasius sutchi) as a source of gelatin (without bioactivities analysis) was obtained. The most alternative source of gelatin came from fish processing products, especially skin and bone. Previous studies showed that the gelatin from the bone of Pangasius catfish had a better gelatin yield and ash composition than the commercial gelatin (Mahmoodani et al. 2014b). In addition, this source was also abundant in Indonesia. Figure 1 presents three series of stages to obtain the fishbone gelatin after hydrolysis. 


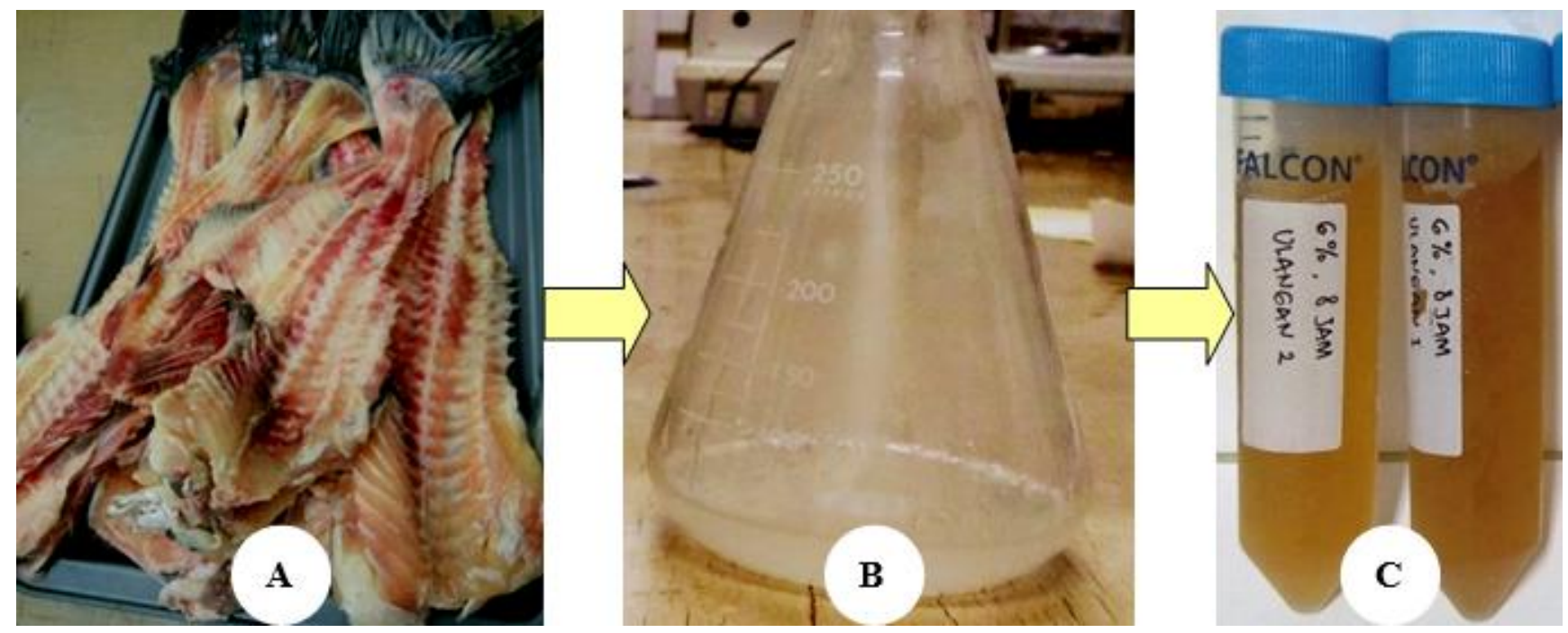

Figure 1. The fishbone (A), gelatin before (B) and after hydrolysis (C) derived from Pangasius catfish

Hydrolysis is one of the key parts of producing bioactive peptides. The successful process of the hydrolysis would determine the activities of peptides. Most of the gelatin from fish processing products was hydrolyzed by the enzymatic method. Some enzymes have been used for the hydrolysis of gelatin, such as alcalase, flavourzyme, pepsin, trypsin, chymotrypsin, bromelain, and papain (Choonpicharn et al., 2014; Himaya et al., 2012; Zhang et al. 2012; Li-Chan et al. 2012; Wang et al. 2015). The research of Li-Chan et al. (2012) concluded that the gelatin from fish processing products was the best in their bioactivities after hydrolyzed using flavourzyme. Some fish-based gelatin hydrolyzed using flavourzyme to obtain the bioactive peptides was gelatin from the skin of tuna, nila tilapia, and salmon (Atma 2016).

\section{Hydroxyproline content}

Hydroxyproline is one dominant amino acid in gelatin besides glycine, proline, alanine, and glutamic acid (Atma 2017). The hydroxyproline was analyzed to determine the extraction yield, representing the successful process of the extraction in gelatin production (Mahmoodani et al. 2014b; Sanei et al. 2013). Recently, most research regarding gelatin extraction from fish skin, bone, head, or other parts usually quantified their hydroxyproline content. This amino acid is unique and has become a differentiator between gelatin and other proteins (Taheri et al., 2009; Sanei et al., 2013). This study analyzed the hydroxyproline content of fishbone gelatin from Pangasius catfish before and after enzymatically hydrolysis. The quantification of hydroxyproline was done to determine the influence of enzymatic hydrolysis of fishbone gelatin toward hydroxyproline concentration.

In quantifying hydroxyproline, a series of standard hydroxyproline solutions were set up. It is to quantify the linear curve for determining the relation between hydroxyproline absorbance and hydroxyproline concentration. In this research, the standard hydroxyproline concentration was in the range of $0-1 \mu \mathrm{g}$, and the linear curve of the standard hydroxyproline solution was $y=0.0554 x+0.0406$ with the coefficient of determination $\left(R^{2}\right)=0.9435$. Figure 2 presents the standard curve of hydroxyproline in a concentration ranging from $0-1 \mu \mathrm{g}$.

Based on the linear equation of the hydroxyproline standard curve, the hydroxyproline content in sample gelatin was quantified. The y value is the absorbance at 560 $\mathrm{nm}$ wavelengths, while the $\mathrm{x}$ is the quantified hydroxyproline concentration. Table 1 presents the hydroxyproline content of fishbone gelatin from Pangasius catfish at different incubation times during enzymatic hydrolysis. The quantification was done on twice repetitions with the average of hydroxyproline of gelatin from the fishbone of Pangasius catfish was from $18.91 \pm 2.87 \mathrm{mg} / \mathrm{mL}$ to $63.81 \pm 1.28 \mathrm{mg} / \mathrm{mL}$. The hydroxyproline content of gelatin before the hydrolysis process was lower than after the hydrolysis process. In this research, the fishbone gelatin was hydrolyzed using $6 \%$ flavourzyme and incubated for $4 \mathrm{~h}$ and had a higher hydroxyproline content than other fishbone gelatin.

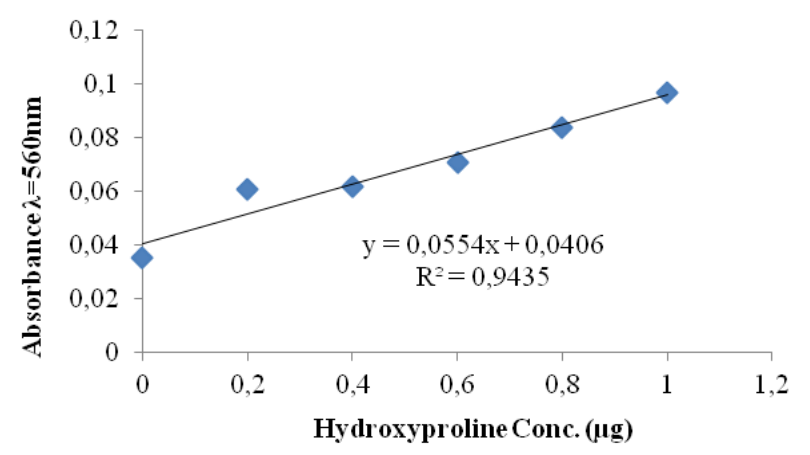

Figure 2. The standard curve for absorbance at wavelength 560 $\mathrm{nm}$ of hydroxyproline in the concentration range of $0-1 \mu \mathrm{g}$ 
Table 1. The hydroxyproline content on fishbone gelatin from Pangasius catfish (Pangasius sutchi) at different times of incubation during enzymatic hydrolysis

\begin{tabular}{lccc}
\hline \multirow{2}{*}{$\begin{array}{l}\text { Hydrolysis incubation } \\
\text { time }\end{array}$} & \multicolumn{3}{c}{ Hydroxyproline content $(\mathbf{m g} / \mathbf{m L})$} \\
\cline { 2 - 4 } & $\mathbf{1}$ & $\mathbf{2}$ & Average \\
\hline 0 h (before hydrolysis) & 16.88 & 20.94 & $18.91 \pm 2.87 \mathrm{a}$ \\
4 h & 62.91 & 64.71 & $63.81 \pm 1.28 \mathrm{~b}$ \\
6 h & 45.31 & 47.11 & $46.21 \pm 1.28 \mathrm{c}$ \\
8 h & 37.18 & 38.09 & $37.64 \pm 0.64 \mathrm{~d}$ \\
\hline
\end{tabular}

Note: Average are mean \pm standard deviation from twice analysis. Value of average in row bearing different letters are significantly different at $\mathrm{p}<0.05$

\section{Discussion}

Hydroxyproline is an amino acid contained in fishbone gelatin, around 5.3-9.6\% (Atma 2017). The study conducted by Mahmoodani et al. (2014b) stated that fishbone gelatin from Pangasius catfish contained hydroxyproline $5.97 \mathrm{~g} / 100 \mathrm{~g}$. It means around $5970 \mathrm{mg} / \mathrm{mL}$ hydroxyproline was obtained from the fishbone gelatin of Pangasius catfish. In this study, Pangasius catfish's gelatin contained about $18.91 \mathrm{mg} / \mathrm{mL}$ of hydroxyproline. However, the extraction method in the research conducted by Mahmoodani et al. (2014b) used hydrochloric acid (strong acid) in the pre-treatment, while this study used citric acid in the pre-treatment. The extraction method of gelatin affected the yield of hydroxyproline. Therefore, the hydroxyproline content in the previous study was higher. Furthermore, Mahmoodani et al. (2014b) optimized the gelatin extraction by response surface methodology, whereas no optimization is done in this study. The optimized condition for gelatin extraction from Pangasius catfish bone is obtained by pre-treatment using hydrochloric acid. However, this chemical utilization for extraction has been limited because of safety and environmental issues consideration.

In this study, the hydroxyproline content increased after the hydrolysis process. The higher hydroxyproline concentration was on fishbone gelatin incubated for $4 \mathrm{~h}$ $(63.81 \mathrm{mg} / \mathrm{mL})$. The hydrolysis of a polypeptide chain probably caused the increase in hydroxyproline content in gelatin, so it increased the detectable amount of hydroxyproline. The hydroxyproline content decreased if the incubation time was longer ( 6 and $8 \mathrm{~h}$ ). It might cause by the denaturation or another factor that influences the hydroxyproline in the gelatin solution for being detected. The hydroxyproline content of fishbone gelatin during various incubation times was significantly different $(\mathrm{p}<$ 0.05) in each treatment (Figure 3).

Overall, the hydroxyproline concentration in this research is different from other studies. Li-Chan et al. (2012) reported that the hydrolysis of gelatin derived from Atlantic Salmon skin using flavourzyme found that the gelatin contained hydroxyproline with a concentration around $88.24 \mathrm{mg} / \mathrm{mL}$. Furthermore, Li Chan et al. (2012) also used an enzyme with the concentration of $6 \%$ enzymesubstrate $[\mathrm{E} / \mathrm{S}]$ in order to obtain the gelatin hydrolysate with the inhibitory activity toward dipeptidyl peptidase IV (DPP-IV) as an antidiabetic treatment approach. Previously, Benjakul et al. (2009) also measured the hydroxyproline of gelatin from two species of bigeye snapper, i.e., Priacanthus tayenus and Priacanthus macracanthus, with the result of the hydroxyproline content in each species were $87.75 \mathrm{mg} / \mathrm{mL}$ and 90.86 $\mathrm{mg} / \mathrm{mL}$, respectively. This has been done to characterize the gelatin from the fish skin of the bigeye snapper. Another study conducted by Sun et al. (2012) was conducted to analyze the antiphotoaging, and antioxidant activity of gelatin from Tilapia (Oreochromis niloticus) using in vivo method,. The hydroxyproline was quantified after the gelatin was fed to mice. Furthermore, the hydroxyproline in mice after feeding was $50 \mathrm{mg} / \mathrm{kg}, 100$ $\mathrm{mg} / \mathrm{kg}$ and $200 \mathrm{mg} / \mathrm{kg}$ fish gelatin were $0.018 \mathrm{mg} / \mathrm{mL}$, $0.020 \mathrm{mg} / \mathrm{mL}$ and $0.022 \mathrm{mg} / \mathrm{mL}$ respectively (Sun et al. 2012). The hydrolysis of fish skin gelatin in the animal's intestine occurs due to the protease that contains in the digestive tract (Tabata et al., 2017).

The hydroxyproline content of fish bone gelatin was affected by enzymatic hydrolysis. The enzymatic hydrolysis increased the hydroxyproline content. The hydrolysis with flavourzyme $(6 \%$ enzyme/substrate concentration) was better during $4 \mathrm{~h}$ incubation than 6 and 8 h. Nevertheless, their bioactivities are the most important in hydrolysis gelatin for producing the bioactive peptide.

\section{ACKNOWLEDGEMENTS}

This study is part of Research Grant of Penelitian Kerjasama Antra Perguruan Tinggi (PKPT). We would like to acknowledge the Ministry of Research, Technology and Higher Education of the Republic of Indonesia (RISTEKDIKTI) for providing the research fund.

\section{REFERENCES}

Aleman A, Gimenez B, Montero P, Gomez-Guillen MC. 2011. Antioxidant activity of several marine skin gelatins. Food Sci Technol 44: 407-413.

Atma Y. 2016. Pemanfaatan limbah ikan sebagai sumber alternatif produksi gelatin dan peptida bioaktif. Prosiding Seminar Nasional Sains dan Teknologi. Universitas Muhammadiyah, Jakarta, 8-9 November 2016. [Indonesian]

Atma Y. 2017. Amino acid and proximate composition of fish bone gelatin from different warm-water species: A comparative study. IOP Conf. Series: Earth and Environmental Science 58: 1-5. DOI:10.1088/1755-1315/58/1/012008

Benjakul S, Oungbho K, Visessanguan W, Thiansilakul Y, Roytrakul S. 2009. Characteristics of gelatin from the skins of bigeye snapper, Priacanthus tayenus and Priacanthus macracanthus. Food Chem 116: 445-451.

Choonpicharn S, Jaturashita S, Rakariyatham N, Suree N, and Niamsup H. 2014 Antioxidant and antihypertensive activity of gelatin hydrolysate from Nile tilapia skin. J Food Sci Technol 52 (5): 3134-3139.

Gomez-Guillen MC, Gimenez B, Lopez-Caballero ME, Montero MP. 2011. Functional and bioactive properties of collagen and gelatin from alternative sources: A review. Food Hydrocolloids 25: 18131827.

Gomez-Guillen MC, Perez-Mateos M, Gomez-Estaca J, Lopez-Caballero E, Gimenez B, Montero P. 2009. Fish gelatin: a renewable material for developing active biodegradable films. Trends Food Sci Technol 20: 3-16.

Himaya SWA, Ngo D, Ryu B, Kim S. 2012. An active peptide purified from gastrointestinal enzyme hydrolysate of Pacific cod skin gelatin 
attenuates angiotensin-1 converting enzyme (ACE) activity and cellular oxidative stress. Food Chem 132: 1872-1882.

Karayannakidis, PD, Zotos, A. 2016. Fish processing by-products as a potential source of gelatin: a review. J Aquat Food Prod Technol 25 (1): 65-92.

Koli JM, Sagar BV, Kamble RS, Sharangdhar ST. 2014. Functional properties of gelatin extracted from four different types of fishes: a comparative study. Indian J Fund Appl Life Sci 4 (4): 322-327.

Li-Chan ECY, Hunag SL, Jao CL, Ho KP, Hsu KC. 2012. Peptides derived from Atlantic salmon skin gelatin as dipeptidyl-peptidase IV inhibitors. J Agric Food Chem 60: 973-978.

Mahmoodani F, Ghassem M, Babji AS, Yusop SM, Khosrokhavar R. 2014a. ACE inhibitory activity of pangasius catfish (Pangasius sutchi) skin and bone gelatin hydrolysate. J Food Sci Technol. 51(9): 1847-1856.

Mahmoodani F, Ardekani VS, See SF, Yusop SM, Babji AS. 2014b. Optimization and physical properties of gelatin extracted from pangasius catfish (Pangasius sutchi) bone. J Food Sci Technol 51 (11): 3104-3113.

Mariod, A. A., AH Fadul. 2013. Review: Gelatin, source, extraction and industrial applications. Acta Scientiarum Polonorum, Technologia Alimentaria 12 (2), 135-147.

Nikoo M, Benjakul S, Ehsani A, Li J, Wu F, Yang N, Xu B, Jin Z, Xu X. 2014. Antioxidant and cryoprotective effect of a tetrapeptide isolated from Amur sturgeon skin gelatin. J Funct Food 7: 609-620.
Nurul AG, Sarbon NM. 2015. Effects of pH on functional, rheological and structural properties of eel (Monopterus sp.) skin gelatin compared to bovine gelatin. Intl Food Res J 22 (2): 572-583.

Sanaei AV, Mahmoodani F, See SF, Yusop SM, Babji AS. 2013. Optimization of gelatin extraction and physicochemical properties of catfish (Clarias gariepinus) bone gelatin. Intl Food Res J 20 (1): 423430.

Tabata E, Kashimura A, Wakita S, Ohno M, Sakaguchi M, Sugahara Y, Kino Y, Matoska V, Bauer PO, Oyama F. 2017. Gastric and intestinal proteases resistance of chicken acidic chitinase nominates chitincontaining organisms for alternative whole edible diets for poultry. Sci Rep 7: 6662.

Taheri A, Kenari AMA, Gildberg A, Behnam S. 2009. Extraction and physicochemical characterization of greater lizardfish (Saurida tumbil) skin and bone gelatin. J Food Sci 74 (3): 160-165.

Wang TY, Hsieh CH, Hung CC, Jao CL, Chen MC, Hsu KC. 2015. Fish skin gelatin hydrolysates as dipeptidyl peptidase IV inhibitors and glucagon-like peptide-1 stimulators improve glycaemic control in diabetic rats: a comparison between warm-and cold-water fish. J Funct Foods 19: 330-340.

Zang Y, Duan X, Zhuang Y. 2012. Purification and characterization of novel antioxidant peptides from enzymatic hydrolysates of Tilapia (Oreochromis niloticus) skin gelatin. Peptide 38: 13-21. 